\title{
Health under austerity in Europe
}

Citation for published version (APA):

Brall, C. (2018). Health under austerity in Europe: ethical considerations. [Doctoral Thesis, Maastricht University]. Maastricht University. https://doi.org/10.26481/dis.20180709cb

Document status and date:

Published: 01/01/2018

DOI:

10.26481/dis.20180709cb

Document Version:

Publisher's PDF, also known as Version of record

\section{Please check the document version of this publication:}

- A submitted manuscript is the version of the article upon submission and before peer-review. There can be important differences between the submitted version and the official published version of record.

People interested in the research are advised to contact the author for the final version of the publication, or visit the DOI to the publisher's website.

- The final author version and the galley proof are versions of the publication after peer review.

- The final published version features the final layout of the paper including the volume, issue and page numbers.

Link to publication

\footnotetext{
General rights rights.

- You may freely distribute the URL identifying the publication in the public portal. please follow below link for the End User Agreement:

www.umlib.nl/taverne-license

Take down policy

If you believe that this document breaches copyright please contact us at:

repository@maastrichtuniversity.nl

providing details and we will investigate your claim.
}

Copyright and moral rights for the publications made accessible in the public portal are retained by the authors and/or other copyright owners and it is a condition of accessing publications that users recognise and abide by the legal requirements associated with these

- Users may download and print one copy of any publication from the public portal for the purpose of private study or research.

- You may not further distribute the material or use it for any profit-making activity or commercial gain

If the publication is distributed under the terms of Article $25 \mathrm{fa}$ of the Dutch Copyright Act, indicated by the "Taverne" license above, 
Summary 


\section{Summary}

Recent developments in several EU countries such as Greece, Spain or Portugal have shown that the economic crisis, that started in 2008, had and still has an adverse impact on social arrangements, and as a result particularly on the health of citizens. Striving for economic recovery, governments of the above mentioned countries are required by the so-called Troika - consisting of the International Monetary Fund, the European Central Bank and the European Commission - to implement austerity measures. Yet, austerity measures are not only highly contested by economists. They also potentially come into conflict with justice, equity and solidarity - values that are considered to be central to the European Union including its health systems.

The objective of this thesis is therefore to discuss the consequences of austerity and scarcity resulting from the economic crisis of 2008 on health in European and particularly EU contexts by taking an ethical perspective.

Arguing from a right to well-being and justice point of view, an ethical assessment is performed, addressing distinct areas within the field of health, namely health and health care provision (part one), pharmaceutical innovation and research (part two) and policy-makers (part three). Whereas part 1 and 2 apply normative ethical frameworks or assessments, part three involves an interview study.

In part one, existing knowledge about the consequences of austerity measures resulting from the economic crisis is assessed by applying the 'capabilities approach of justice' (CA) by Amartya Sen (stemming from the consequentialist realm) and the Bioethical Imperative by Fritz Jahr (representing a deontological theory) in juxtaposition to the often used consequentialist principle of 'first do no harm' introduced parenthetically as an ethical criterion by austerity and health researchers Stuckler and Basu.

The assessment shows that health outcomes were and are impacted in a negative way, not only in terms of adverse effects on equality of opportunity to gain or stay in good health. Beyond that, the CA reinforces that health - and in particular the capability for health - should not be neglected in policy-making, but should constitute a key component within respective policies. It highlights where policy representatives should provide burdens of proof for certain actions, among them why Germany followed a different policy approach (stimulating its economy) as it itself imposed - via the Troika - on other countries (which had to adopt austerity measures, as for instance Greece). The CA moreover shows that the success of policies should not only be considered within terms of overall life expectancy, incidence and mortality rates, but rather the distribution thereof within societies. Measures should involve other information about the well-being of human beings, both on overall population level, as well as taking into account the individual level, thus stressing the need to strengthen social safety nets.

Jahr's account adds a Kantian perspective that sees persons as an end in themselves and not as a means, reminding not to use people for the benefit of others. While 'first 
do no harm' focuses on a minimalist morality, Jahr's Bioethical Imperative points more towards the positive value of creating benefits and the conditions for dignity, selfrespect and respect for others. Specific actions according to Jahr's Imperative are identified for increasing public health during scarcity, such as

- supporting economically weak by strengthening social safety nets (in accordance with Keynesian ideology),

- $\quad$ strengthening advocacy towards health needs, e.g. by media coverage,

- $\quad$ increasing health literacy so as to avoid unhealthy habits,

- $\quad$ ensuring vital needs in line with equality of opportunity, e.g. through access to health care,

- actively engaging in health-promoting policies in line with principles of beneficence.

Part two aims to address the ethical challenges of scarce resources in the specific context of personalised medicine and research.

Regarding the former, it is asked under what conditions new investments in innovative therapies such as personalised medicine are justifiable. The CA answers this question with the need for investing in treatments that might be necessary for survival. Taking into account the importance of individual and societal freedoms or opportunities, and especially the so-called 'conversion factor', the CA specifies that only individuals with corresponding genetic biomarkers are able to achieve a 'real benefit' from personalised treatments. In terms of scarcity of resources, it can thus be regarded as efficient to only offer treatment to those who can benefit and thus attain better health from personalised medicine, and to reduce the expenses of futile treatments for persons who do not possess matching genetic biomarkers. Social arrangements can help to promote research and development of personalised medicines and introducing reimbursement schemes with the goal to enable access to those therapies for those who can achieve 'real options' to benefit from personalised medicine. This can reduce opportunity costs in an environment of scarce resources, while efficiency, equity and access can be safeguarded.

In research, ethical conduct is anew in the spotlight due to increased competition arising from scarce resources and limited funding opportunities. A network of responsibilities is established as a heuristic framework through which changes and complexities in research ethics are modelled and can be systematically conceived. It takes into account the broader social dimension of research by identifying six other main stakeholders besides the researcher, which are: research subjects, colleagues, editors/publishers, professional associations, society at large and - especially relevant in times of economic crisis and austerity - universities and funders. Integrity of research is challenged on diverse levels, and can be addressed by applying the network of responsibilities. Focusing on research ethics and integrity on diverse levels and taking into account all stakeholders can make research better, more truthful and thereby more socially acceptable, which is important since it influences support for research in general, which in times of scarcity is often reduced. By promoting 
accountability and public trust through such network of mutual responsibilities and rights, emphasis on moral values can be regarded as a driver for science, especially in times of increased competition.

In part three, an explorative interview study assesses how European policy-makers perceive the economic crisis with regard to health and ethics in decision-making. All interviewees recall difficult and strenuous situations where they had to prioritize between distinct areas to focus on and invest in, for example around choices between medications, health professional staffing, care specific equipment, or urgent infrastructure issues. Values are identified which they deemed as important within the policy-making process, such as trust and responsibility. Policy-makers furthermore report about possible health policy measures in response to the crisis, which they think could improve the overall health situation of EU citizens. Among them are the prioritisation of vulnerable groups, enforcing empowerment and health literacy as an instrument for saving costs, not cutting preventive care and spending more on health while reducing spending in other sectors, e.g. defence. They explicitly express the need for ethical tools and assistance in terms of policy advice for reaching morally sustainable decisions in health policy matters. The study shows that ethical concepts and values frequently come into play in health policy-making, and that ethics is highly relevant in policy-makers' daily decision-taking.

In the final chapter, the identified ethical aspects of austerity and relevant health values, which should be focused upon in policy-shaping, are discussed. Even though they would not seem crucial in a context of non-austerity, focus on such aspects increases the social emphasis in otherwise merely economically oriented questions and policy approaches. It is furthermore conceded that academic views about the severity of adverse effects of the crisis remain diverse. Despite those different perspectives about the severity of consequences on health and health care, the ethical assessment points towards the importance of not only looking towards overall population health, but that every single individual should be taken care of in terms of health and access to health care provision and should not be 'left behind'. The established public health policy network offers an ethical perspective involving responsibilities of and towards all stakeholders involved. It is concluded that the thesis carved out some conditions and values that can provide policy-making with a better ethical basis, contributes to what is at stake during austerity in terms of ethics in the fields of health and health care provision, pharmaceutical innovation and research, and for European policy-makers, and intents to bring ethics more on the agenda in actual public health debates. 
